NUREG/CR-0892

PNL-3045

\title{
Chronic Effects of Chlorination By-Products on Rainbow Trout, Salmo gairdneri
}

Prepared by D. R. Anderson, R. M. Bean, R. E. Schirmer

Pacific Northwest Laboratory

Operated by

Battelle Memorial Institute

Prepared for

U.S. Nuclear Regulatory

Commission 


\section{NOTICE}

This report was prepared as an account of work sponsored by an agency of the United States Government. Neither the United States Government nor any agency thereof, or any of their employees, makes any warranty, expressed or implied, or assumes any legal liability or responsibility for any third party's use, or the results of such use, of any information. apparatus product or process disclosed in this report, or represents that its use by such third party would not infringe privately owned rights.

Available from

GPO Sales Program

Division of Technical Information and Document Control

U. S. Nuclear Regulatory Commission Washington, D. C. 20555

and

National Technical Information Service

Springfield, Virginia 22161 
NUREG/CR-0892

PNL-3045

RE

\section{Chronic Effects of Chlorination By-Products on Rainbow Trout, Salmo gairdneri}

Manuscript Completed: October 1980

Date Published: November 1980

Prepared by

D. R. Anderson, R. M. Bean, R. E. Schirmer

Pacific Northwest Laboratory

Richland, WA 99352

\section{Prepared for}

Division of Safeguards. Fuel Cycle and Environmental Research

Office of Nuclear Regulatory Research

U.S. Nuclear Regulatory Commission

Washington, D.C. 20555

NRC FIN No. B2098 

Rainbow trout were exposed to by-products of low-level water chlorination for several months in two separate experiments. In each test 2400 juvenile rainbow trout (Salmo gairdneri) were reared under chlorination conditions designed to simulate those of a power plant. Objectives were to determine effects of long term exposure to provide samples for tissue analysis of chlorination byroducts. No significant difference in fish condition factors was found between the test groups and controls, neither was there an apparent effect on mortality.

Background levels of chloroform were found in all fish, but there was no evidence of an increased amount of chloroform or other chlorination by-products resulting from chronic low level exposure to chlorination by-products. 

This report describes two separate experiments in which rainbow trout were exposed to by-products of low-ievel chlorination of water for six months. In both tests 2400 juvenile rainbow trout were reared under five dilutions of water chlorinated with $\sim 1-2 \mathrm{ppm}$ total residual chlorine (TRC). The five concentrations tested had a maximum of $0.02 \mathrm{ppm}$ TRC. Study objectives were to determine effects of long term exposure on mortality and to provide samples for tissue analysis of chlorination by-products.

No apparent chronic effect on mortality was observed from chlorination byproducts under the experimental time and exposure conditions. No significant differences were found in length or weight between controls and test groups at most subsamplings. No significant difference was found in fish condition factors between the test groups and controls. While chloroform, a chlorination by-product, was found in all fish, there was no evidence of increased chloroform as a result of low level exposure to chlorination by-products. 



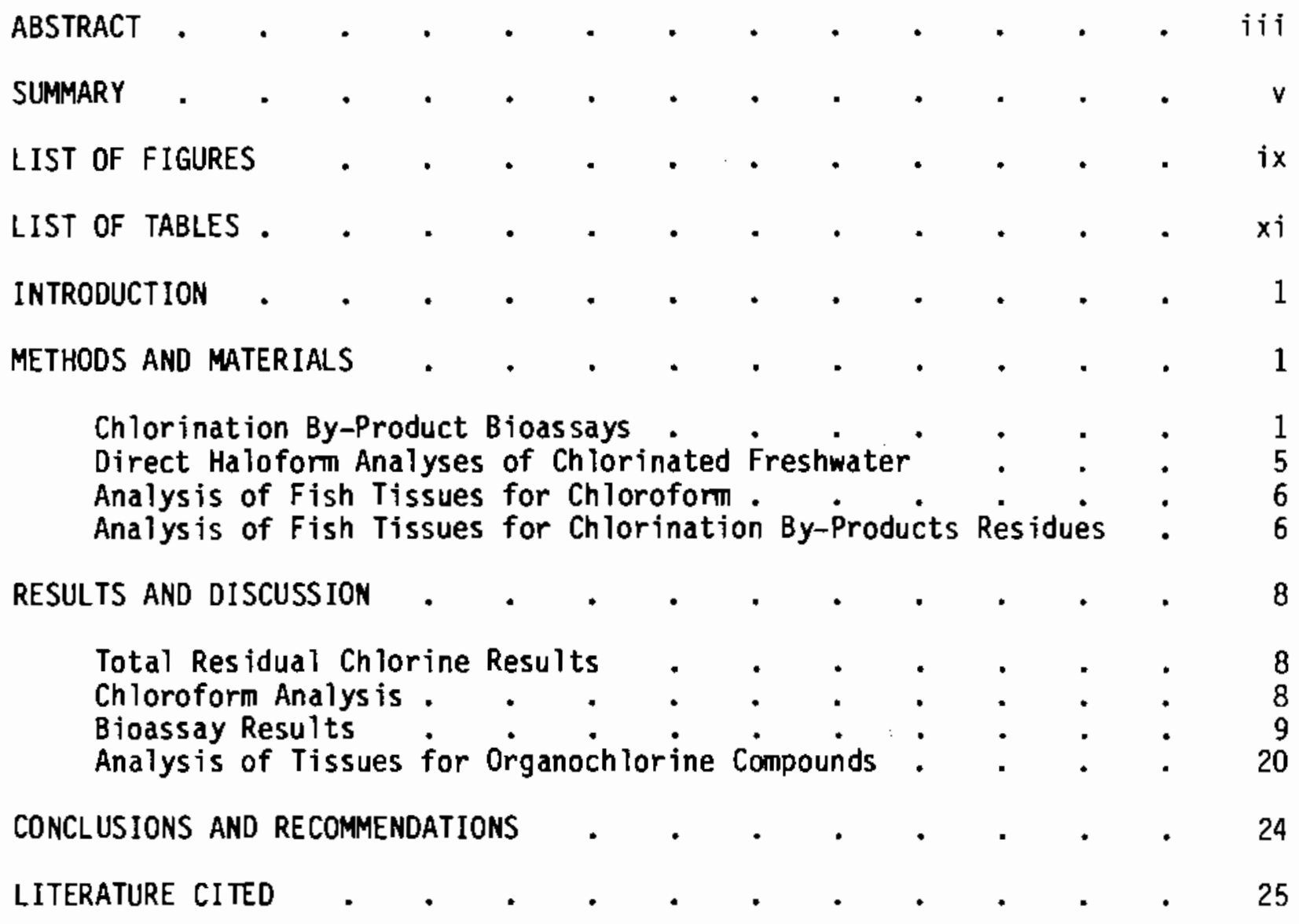




\section{FIGURES}

1. Chlorination By-Product Delivery System Used in the First Test . 3

2. Exposure System for Chlorination By-Products During the

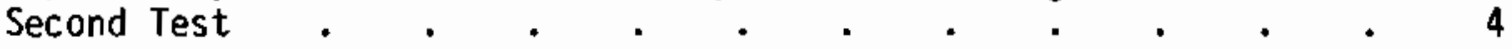

3. Characterization of Fractions from Gel Permeation Chromatography of Extracts of Tissues from (A) Control and (B) Exposed Rainbow Trout . . . . . . . . . 23 



\section{TABLES}

1. Mean and Standard Deviation of Total Residual Chlorine (TRC)

in Parts per Million Measured by Amperometric Titration During

the First Six Month Bioassay . • . • . • . . 8

2. Chloroform Headspace Analys is of the Freshwater Low-Level

Chlorination Experiment with Rainbow Trout . . . . . 9

3. An Accounting of Rainbow Trout Mortalities During the First

Six Month Bioassay of ChTorination By-products . . . . 10

4. An Accounting of Rainbow Trout Mortalities During the Second Six Month Bioassay of Chlorination By-products . • . . 11

5. Fork Length in Centimeters of Rainbow Trout Subsampled at 3 and 6 Months During the First Chronic Chlorination By-Product Test

6. Weight in Grams of Rainbow Trout Subsampled at 3 and 6 Months During the First Chronic Chlorination By-product Test. . . . 13

7. Data Summary of Growth Data at the 6 Month Sampling in the First Chronic Chlorination By-Product Test . . . . . 14

8. Condition Factor of Rainbow Trout Subsampled at 3 and 6 Months During the First Chronic Chlorination By-Product Test . . . 15

9. Fork Length in Centimeters of Rainbow Trout During the 2nd Chlorination By-Product Bioassay . . . . . . . 17

10. Weight in Grams of Rainbow Trout During the 2nd Chlorination By-Product Bioassay. . . . . . . . . . 18

11. Condition Factors for Rainbow Trout During the 2nd Chlorination By-Product Bioassay. . . . . . . . . . 19

12. Est imated Chloroform in Rainbow Trout Tissue . . . . . 20

13. Characterization of Crude Extracts of Fish Tissues from the First Bioassay. . . . . . . . . 



\section{PREFACE}

This report includes data and analysis for Freshwater Biology Task of the program on Biocide By-Products in Aquatic Environments.

Reports prepared for the entire program are:

\section{Title}

- Investigation of Halogenated Components Formed from Chlorination of Natural Waters: Preliminary Studies, NUREG/CR-1299

- Acute Toxicity and Bioaccumulation of Chloroform to Four Species of Freshwater Fish

Salmo gairdneri, Rainbow Trout

Lepomis macrochirus, Bluegill

Micropterus salmoides, Largemouth Bass

Ictalurus punctatus, Channel Catf ish NUREG/CR-0893

- Chronic Effects of Chlorination By-Products on Rainbow Trout, Salmo gairdneri, NUREG/CR-0892

- Toxicity, Bioaccumulation and Depuration of Bromoform in Five Marine Species

Protothaca staminea, Litt leneck Clam

Mercenaria mercenaria, Eastern Hard Clam, Quahog

Crassostrea virginica, Eastern oyster

Penaeus aztecus, Brown Shrimp

Brevoortía tyrannus, At lantic Menhaden, NUREG/CR-1297

- Growth and Histological Effects to Protothaca staminea, (Littleneck Clam) of Long-Term Exposure to ChTorinated Sea water, NUREG/CR-1298

- Analysis of Organohalogen Products from Chlorination of Natural Waters Under Simulated Biofouling Control Conditions, NUREG/CR-1301

- Biocide By-Products in Aquatic Environments, Final Report Covering Period September 10, 1976 through September 30, 1979, NUREG/CR-1300

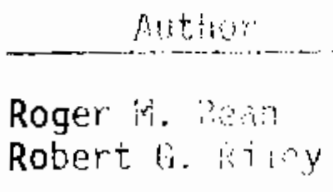

David R. Anderson E. William Lusty

David R. Anderson Roger M. Bean Roger E. Schirmer

Chalres I. Gibson Fredrick 6. Tone Peter Wilkirson J. W. Bloyrock Roger E. Stitrmer

Charles I. Gibson Robert E. II? Iman Peter Wilkirion Dana L. Hoadruff

Roger M. Bean Dale C. Mann Robert 6 . $R$ i i $a y$

Roger M. Bean Charles I. Gibson David R. Arderson 


\section{ACKNOWLEDGMENTS}

This work was performed for the U.S. Nuclear Regulatory Commission under a Related Services Agreement with the U.S. Department of Energy, Contract DE-ACO6-76RLO 1830. The authors wish to acknowledge the guidance and assistance provided by Dr. Phillip R. Reed of NRC. They also thank T. L. Page for criticaliy reviewing the manuscript. Naomi Sherer provided technical editing.

\section{DISCLAIMER}

Trade names and registered trademarks are used for reader convenience and their use does not imply endorsement by Battelle Memorial Institute or the Nuclear Regulatory Commission. 

This report contains results of a portion of our studies of effects of chlorination by-products on selected fauna in fresh-water and marine environments. The objectives of this phase of the study were to determine long-term toxic effects of total chlorination by-products on juvenile rainbow trout (Salmo gairdneri) and to provide tissues for analys is of chlorination by-products. observations were also make on fish growth. To accomplish these objectives two 6-mo partial-chronic toxicity tests were conducted.

The study was designed to examine toxicity, other than acute toxicity of Total Residual Chlorine (TRC), and potential hazard to aquatic fauna of chlorination at steam electric power plants. Rainbow trout were selected because of their economic and ecological importance in power plant receiving waters and established use as a laboratory test organism.

Two chronic tests were conducted with experimental systems designed to chiorinate river water at 1-2 ppm TRC, the range found during power plant chlorination. Chlorinated water was then diluted to contain low levels of TRC and byroducts generated by chemical reactions of chlorine with other materials in the water. By-products of interest are chlorinated organics that are readily available and accumulated by biota. Acute toxicity tests of TRC were not conducted since its toxicity is well documented in the literature (Brungs 1973: 1976). Since chlorinated organics produced during chlorination are determined by the organic precursors in the water, the Columbia River was an excellent source because it contained few industrially-related contaminants that may have influenced the results.

Development of analytical capability to determine specific chlorinated organics occurred in parallel with the toxicity tests. Results of this work are published separately (Bean et al. 1980).

METHODS AND MATERIALS

Chlorination By-Product Bioassays

In each test 2400 juvenile rainbow trout (Salmo gairdneri) from Battelle's hatchery stock were reared under chronic chlorination conditions designed to simulate chlorination concentrations from a power plant. Each of 12 aquaria were stocked with $200 \mathrm{fish}$. There were two aquaria for each of the five test concentrations plus two controls. Fish were randomly distributed in the aquaria. Fish biomass in each aquarium was maintained at less than $0.5 \mathrm{~g}$ fish/l of water/day as recommended by Sprague (1973), by scheduled periodic subsampling during the 6 mo period. All subsampled fish were weighed, measured and some analyzed for chlorination by-product accumulation.

During the first test, the chlorination rate was controlled to maintain a constant chlorine residual. This required additional chlorine as the chlorine demand increased during the summer. For the second test a constant chlorination rate was used. 
The method used in the first test permits a potential increase in production of total chlorination by-products since more chlorine is added to react with the organics. In the second test, the chlorination rate required to maintain an initial TRC concentration of $20 \mathrm{ppb}$ was not changed during the 6-mo test. The latter procedure results in exposure to a more consistent level of chlorination by-products throughout the 6 -mo period than the former. During both tests, the feeding rate of approximately $1 \%$ per day by body weight was adequate to produce growth and was maintained relative to the biomass in each aquaria. This reduced overfeeding and minimized the possibility of chlorinating residual fish food components in the aquaria. Each aquarium was checked daily for fish mortalities. Fish were treated for disease as necessary according to normal hatchery practice.

At each subsampling period, fish from each aquarium were removed and a predetermined number based on projected growth to the next subsampling period were returned to the aquarium. This assured that fish biomass at the next subsampling was less than the maximum levels recommended by Sprague (1973) and ensured that sufficient dissolved oxygen was available.

Coefficient of condition, or condition factor can be calculated as: $k=w / \ell^{3}$ where $K=$ coefficient of condition, $w=$ weight and $\ell=$ length. The relation of length (L) to weight $(w)$ can also be expressed in a general growth formula of $w=L^{3}$ or a regression $\ell n w=\ell n a+B \ell n L$ where $\beta$ is the slope and $\ell$ n $a$ is the length-weight intercept. Length-weight regressions were calculated using this formula and logarithimically transformed to normalize the data.

The test systems provided a continuous flow of chlorinated water with a chlorine contact time of approximately one hour (Fig. 1 and 2). This time interval was chosen for two reasons: 1) it was the approximate time at Haddom Neck (Connecticut Yankee) Nuclear Power Plant between the initial chlorination of cooling water and its final discharge to the cooling water body (Gore et al. 1976) and 2) the contact period allowed for maximum production of chlorination by-products. Although many power plants have less than a 1-hr transit time, $1 \mathrm{hr}$ provides a representative situation in which chlorination by-product formation is maximized.

Each exposure system had replicate aquaria for five levels of toxicant and controls. In the first dilution system flow scheme, Columbia River water at ambient temperature was chlorinated at 1.0-2.0 ppm TRC and then passed through a baffled chlorine contact chamber (contact time $\sim 1 \mathrm{hr}$ ). In the first test undiluted chlorinated water was used for the higher concentration.

In the second test, chlorinated water was diluted to obtain the desired TRL for the highest concentration. This maximum concentration was designated as the 100 percent concentration. In each test the highest concentration was then proportionately diluted to $75,50,25$, and $12.5 \%$. The sequence of test concentrations were randomiy assigned to the test aquaria.

The toxicant delivery system used in the first chlorination by-product test was composed primarily of glass and PVC. The chlorine and river water head tanks were 10 gal Naigene containers. The dilution water manifold and chlorinated 


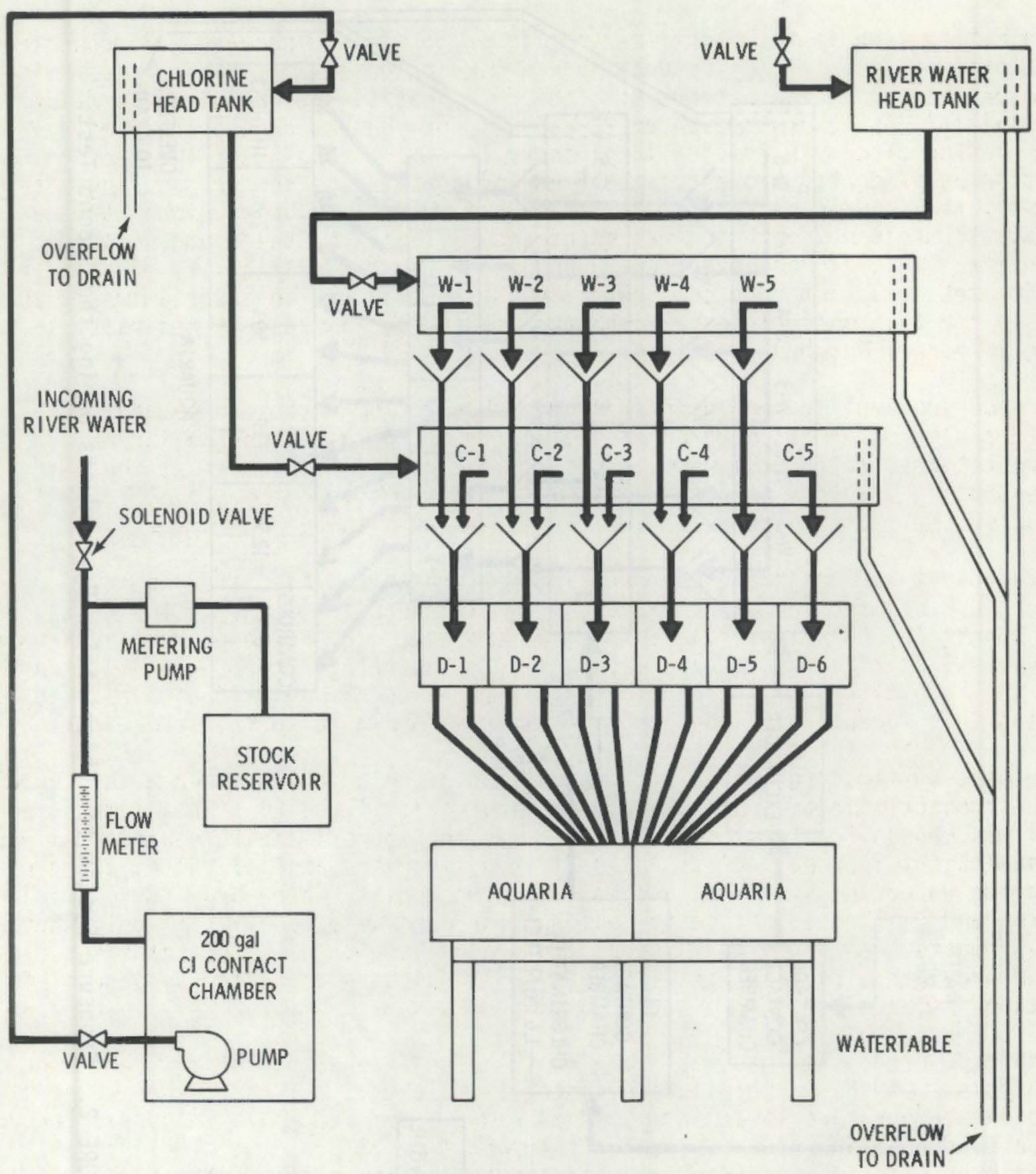

FIGURE 1. Chlorination By-Product Delivery System Used in the First Test. 


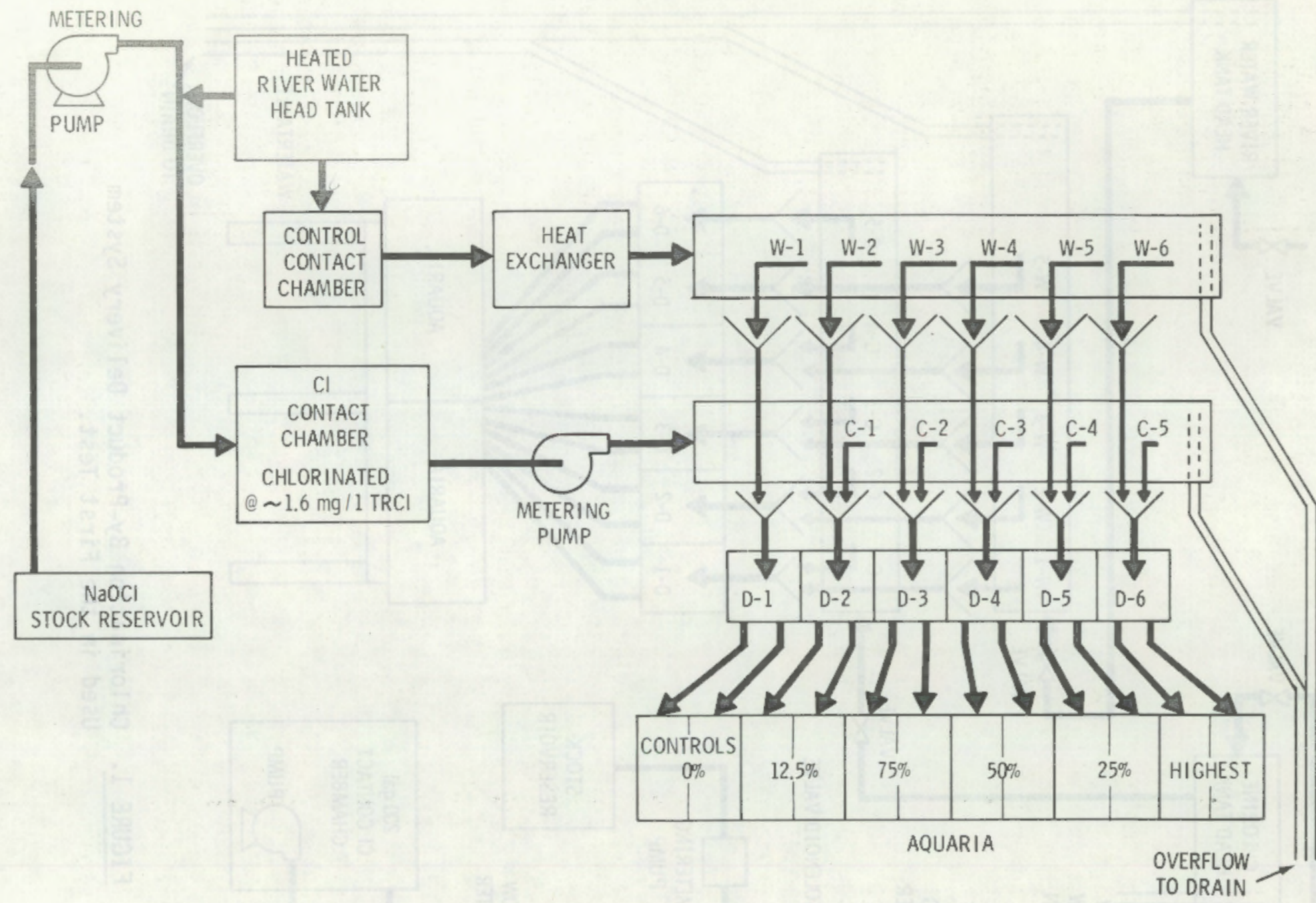

FIGURE 2. Exposure System for Chlorination By-Products During the Second Test. 
water manifold ("w" and "C" cells) were 4-in. (10.2 cm) PVC pipe with a silicone stopper for each glass dripper arm. Water from the "W" and "C" manifolds flowed from the glass dripper arms into long stemed glass funnels and to the glass dilution, "D" cells. The "D" cells were maintained about half full to provide mixing prior to splitting and balancing flows to paired aquaria. Tygon tubing was used from the "D" cells to the 12 glass $50 \%$ aquaria. Aquaria were modified to promote uniform mixing throughout by placing glass panes 4-in. $(10.2 \mathrm{~cm})$ wide the full height of the aquaria across the corners to eliminate the dead space normally formed. Dye studies showed this configuration promoted uniform mixing throughout the aquaria. Water was removed from the bottom of the aquaria through a $1-i n .(2.54 \mathrm{~cm})$ PVC standpipe. The chlorine stock reservoir was a 5 -gal $(18.9$ l) glass carboy covered with aluminum foil to reduce the potential for photo-induced deterioration of the sodium hypochlorite (NaOCl) stock. A glass syringe pump metered the stock solution into the inflowing water to the baffled 200 gal (757 l) fiber glass contact chamber. The water had approximately 1-hr residence time, estimated with a plug flow model, in the contact chamber before being pumped to the chlorine head tank. Dilution water was thermally-controlled, filtered Columbia River water.

The second exposure system (Fig. 2) was composed of the same materials as the first, except nylon tubing replaced tygon tubing from the "D" cells to the aquaria. For the first 3 mo of the second test, both chlorinated and unchlorinated water temperature was raised $10^{\circ} \mathrm{C}$ above ambient before the contact perjod. The water was cooled to ambient Columbia River water temperature before entering the aquaria. Heating the water more closely simulated power plant conditions. During the last 3-mo of the test, unchlorinated river water was not heated due to problems encountered in cooling the large volume of water. The chlorinated contact chamber was heated $10^{\circ} \mathrm{C}$ above ambient and cooled throughout the test. Since only small amounts of chlorinated water was used in the aquaria, a heat exchanger was not needed for the chlorinated water.

Total residual chlorine measurements were made by amperometric titration in accordance with Standard Methods, 14th Ed (American Public Health Association, 1975). Measurements were made by placing the acetate buffer and potassium iodide solutions in a beaker and adding $200 \mathrm{ml}$ of sample from a volumetric flask. Phenylarsine oxide titrant was added using a microburette. Titration was conducted using a Sargent Welch Polarograph with a rotating mercury electrode. Analyses were made daily for the first month of the test. Daily variability was low and measurement frequency was then reduced to three times a week. TRC measurements were made of water flowing into and out of each aquarium. Reduction in TRC due to chlorine demand in the aquaria was thus monitored.

Direct Haloform Analyses of Chlorinated Freshwater

Part of the biological experiments were designed to determine the long-term effects of low-level chlorination of Columbia River water on salmonids. Chloroform concentrations in the test systems were measured using the headspace sampling method (Bush et a1. 1977). Gases in the headspace of $125 \mathrm{ml}$ glass bottle containing $5 \mathrm{~g} \mathrm{NaCl}, \sim 200 \mathrm{mg} \mathrm{Na} 2 \mathrm{SO}_{3}$, and a $15 \mathrm{ml}$ water sample were analyzed by GC for haloform. 
The analytical phase of the chlorination by-products program determined that a large number of chlorinated compounds were produced in minute quantities (Bean et al., 1980). Chloroform, a major chlorination by-product, was therefore monitored during the second bioassay. Chloroform measurements were not made during the first bioassay.

Analysis of Fish Tissues for Chloroform

Whole fish or fish tissues were immersed in chloroform free methanal (2 ml methanol per gram of tissue) and chilled as soon as they were collected. The presence of methanol was necessary to avoid loss of chloroform from the tissue during storage and subsequent homogenization. If the samples were held more than a few hours before analys is they were kept in a refrigerator in tightly sealed glass containers with as little headspace as possible.

Prior to homogenization, a solution of dichloromethane (interna) standard) in methanol was added to each sample. The amount of dichloromethane added was adjusted to be comparable to the expected amount of chloroform in the sample: one microgram per gram of tissue was used in the present study. The tissue was homogenized in methanol, keeping it chilled in an ice bath. Six ml of water and $5 \mathrm{ml}$ of methyl isobutyl ketone (MIBK) was added for each gram of tissue in the homogenate and the mixture shaken for 10 minutes. The MIBK layer was transferred to a screw cap glass bottle and extracted a second time using the same volume of fresh MIBK. The MIBK from the first and second extractions were combined. About $95 \%$ of the chloroform was extracted by this procedure. The extract was analyzed for chloroform using a gas chromatograph with an electron capture detector fitted with a 2 ' $\times 2$ man Porapak $Q$ column. The column oven was held at $125^{\circ} \mathrm{C}$ for 11.0 minutes, then programmed to $180^{\circ} \mathrm{C}$ at $5{ }^{\circ} \mathrm{C} / \mathrm{min}$ and held there for 10 minutes. Under these conditions and with $25 \mathrm{ml} / \mathrm{min}$ helium carrier flow, the retention times of dichloromethane and chloroform are about 1.2 and $3.0 \mathrm{~min}$, respectively. The high temperature program was used to remove the MIBK and other less volatile tissue components from the column before the next sample was injected. Chloroform standards were prepared in methanol and treated in the same manner as the samples.

Analysis of Fish Tissues for Chlorination By-Products Residues

Tissues from fish used in chronic chlorine bioassays were analyzed for chlorination by-product residues. Procedures of Keuhl and Leonard (1978) were used for initial extraction and separation of components in fish tissues. Tissues were prepared for extraction by grinding whole fish with sufficient anhydrous sodium sulfate to give a dry mass ratio oi approximately $2: 1, \mathrm{Na}_{2} \mathrm{SO}_{4}$ : tissue by weight. Quantities of the dry mixture equivalent to approximately 10 grams of tissue were then extracted overnight in a Soxhlet extractor using $50 \mathrm{ml}$ of 50:50, acetone:hexane. The extraction was actually carried out by the 59:41, acetone:hexane azeotrope which boils at $49.8^{\circ} \mathrm{C}$. The extract from control fish consisted of two phases at this point, apparently due to a larger amount of water in the sample. The difference in water content may have resulted in differences in extraction efficiencies for the two samples. 
Residues remaining in the extraction thimbles after the first extraction were Soxhlet extracted a second time with a fresh charge of $50 \mathrm{ml}$ 50:50, acetone: hexane. The purpose of the second extraction was to verify completeness of the first extraction.

Separation of the components in the extracts according to molecular weight was then made using gel permeation chromatography. Four milliliter aliquots of the crude extracts of exposed and control fish were chromatographed on a $1 \times 28 \mathrm{~cm}$ column packed with Bio-Beads SX-2, 200-400 mesh, and eluted with dichloromethane pumped at $2 \mathrm{ml} / \mathrm{min}$. Ten milliliter cuts of the column eluate were collected over a period of 200 minutes using an automatic fraction collector. Fractions obtained from the first column separation were characterized by their nonvolatile residue content, total chlorine (after evaporation of the dichloromethane solvent), and ultraviolet absorption spectrum. 
RESULTS AND DISCUSSION

\section{Total Residual Chlorine Results}

A summary of the TRC measurements made during the first bioassay is given in Table 1. Due to the chlorine demand in the aquaria the $12.5 \%$ and $25 \%$ concentration test aquaria frequentiy had $<0.001 \mathrm{ppm}$ TRC. The concentration of TRC entering the 50,25 and $12.5 \%$ aquaria averaged less than that calculated by dilution, apparently as a result of the chlorine demand of the dilution water.

TABLE 1. Mean and Standard Deviation of Total Residual Chlorine (TRC) in Parts Per Million Measured by Amperometric Titration During the First Six Month Bioassay.

\begin{tabular}{|c|c|c|c|c|}
\hline Test Group & $\begin{array}{c}\text { Entering } \\
\frac{\bar{x}}{}\end{array}$ & $\begin{array}{c}\text { Aquaria } \\
\mathrm{S}\end{array}$ & In the & $\begin{array}{c}\text { Aquaria } \\
\text { S }\end{array}$ \\
\hline $\begin{array}{c}0 \% \\
12.5 \% \\
25 \% \\
50 \% \\
75 \% \\
100 \\
\text { Contact Chamber }\end{array}$ & $\begin{array}{l}<0.001 \\
0.001 \\
0.004 \\
0.012 \\
0.026 \\
0.034 \\
0.037\end{array}$ & $\begin{array}{l}-\overline{0} \\
0.001 \\
0.003 \\
0.005 \\
0.008 \\
0.011 \\
0.013\end{array}$ & $\begin{array}{r}<0.001 \\
<0.001 \\
<0.001 \\
0.006 \\
0.015 \\
0.021\end{array}$ & $\begin{array}{c}- \\
- \\
- \\
0.005 \\
0.008 \\
0.010\end{array}$ \\
\hline
\end{tabular}

\section{Chloroform Analysis}

Chloroform analyses obtained from the experiments are given in Table 2. The "100\%" sample is the highest level to which the trout are exposed. This level is actually a 16-fold dilution of the concentrate from the chlorine contact chamber. On May 22 and June 16, sampling was limited to one sample per exposure concentration. On May 26, however, five concentrations were sampled in triplicate to determine the method's reproducibility, which was satisfactory.

Chloroform data indicate that in the biological test systems, the amount of chloroform is $1 \mathrm{\mu g} / \mathrm{l}$ or less, and the spread between the highest and lowest concentrations of chloroform is only a factor of two. 
TABLE 2. Chloroform Headspace Analysis of the Freshwater Low-Level Chlorination Experiment with Rainbow Trout. Values reported as $\mu \mathrm{g} \mathrm{CHCl}$.

\begin{tabular}{|c|c|c|c|c|}
\hline & $5 / 22 / 78$ & $5 / 26 / 78$ & $6 / 16 / 78$ & Average \\
\hline Contact Chamber & 31.3 & $40.16 \pm 1.39$ & $39.09 \pm 1.15$ & $36.85 \pm 4.83$ \\
\hline $100 \%$ & $1.05 \pm 0.21(\mathrm{a})$ & $1.03 \pm 0.11$ & 0.93 & $1.00 \pm 0.06$ \\
\hline $75 \%$ & 1.00 & - & 0.83 & $0.92 \pm 0.12$ \\
\hline $50 \%$ & 0.54 & $0.70 \pm 0.00$ & 0.69 & $0.64 \pm 0.08$ \\
\hline $25 \%$ & 0.41 & -- & 0.62 & $0.52 \pm 0.15$ \\
\hline $12.5 \%$ & 0.49 & $0.47 \pm 0.05$ & $0.6(c)$ & $0.52 \pm 0.07$ \\
\hline 0 & 0.46 & -- & $n d(d)$ & 0.23 \\
\hline River Water & 0.46 & $0.39 \pm 0.04$ & -- & $0.43 \pm 0.05$ \\
\hline
\end{tabular}

average of duplicate samples.

banalyses on $5 / 26$ were obtained from triplicate samples.

CEstimate, interference with peak integration.

dNot detected.

\section{Bioassay Results}

Results of the two 6-mo bioassays are summarized in Tables 3 and 4 . Losses from disease were generally low and about equal to other mortality. During the second test fewer fish died of disease in the $25,50,75$ and $100 \%$ concentrations combined than in either the control or $12.5 \%$ concentration. This may be a prophylactic effect of chlorine at the low TRC levels.

Test mortality was low in both bioassays, approximately one fish per aquarium per week. There was no apparent effect on mortality of chronic exposure to low level TRC at any concentration tested.

Losses due to cannibalism in chronic bioassays have been reported by Sprague (1973). Although cannibalism was not observed in the aquaria until the second chronic bioassay, we did observe losses from fish jumping down the 1-in. drain standpipe during feeding and aquarium cleaning during both chronic bioassays. Standpipes were further screened and a catch basket placed in the drain lines to minimize and to account for these losses during the second chronic bioassay. 
TABLE 3. An Accounting of Rainbow Trout Mortalities During the First Six Month Biodssay of Chlorination By-products.

\begin{tabular}{|c|c|c|c|c|c|c|c|c|}
\hline $\begin{array}{c}\text { Test } \\
\text { Concentration }\end{array}$ & $\begin{array}{l}\text { Aquarium } \\
\text { Number }\end{array}$ & $\begin{array}{l}\text { Number } \\
\text { of Fish }\end{array}$ & $\begin{array}{l}\text { No. fish in } \\
\text { Subsample } 1\end{array}$ & $\begin{array}{l}\text { No. fish in } \\
\text { Subsample } 2\end{array}$ & $\begin{array}{l}\text { After Second } \\
\text { Subsample }\end{array}$ & Mortality & $\begin{array}{l}\text { Mishaps } \\
\text { Disease }\end{array}$ & For $\star \star$ \\
\hline $0 \%$ & $\begin{array}{l}2 A \\
2 B \\
\Sigma\end{array}$ & $\begin{array}{l}200 \\
200 \\
400\end{array}$ & $\begin{array}{l}104 \\
110 \\
214\end{array}$ & $\begin{array}{l}30 \\
33 \\
63\end{array}$ & $\begin{array}{l}22 \\
22 \\
44\end{array}$ & $\begin{array}{r}10 \\
1 \\
11\end{array}$ & $\begin{array}{l}2 \\
2 \\
4\end{array}$ & $\begin{array}{l}32 \\
32 \\
64\end{array}$ \\
\hline $12.5 \%$ & $\begin{array}{c}1 \mathrm{~A} \\
1 \mathrm{~B} \\
\Sigma\end{array}$ & $\begin{array}{l}200 \\
200 \\
400\end{array}$ & $\begin{array}{l}106 \\
119 \\
225\end{array}$ & $\begin{array}{l}27 \\
11 \\
38\end{array}$ & $\begin{array}{l}20 \\
22 \\
42\end{array}$ & $\begin{array}{l}11 \\
15 \\
26\end{array}$ & $\begin{array}{l}0 \\
8 \\
8\end{array}$ & $\begin{array}{l}36 \\
25 \\
61\end{array}$ \\
\hline $25 \%$ & $\begin{array}{l}6 \mathrm{~A} \\
6 \mathrm{~B} \\
\Sigma\end{array}$ & $\begin{array}{l}200 \\
200 \\
400\end{array}$ & $\begin{array}{l}128 \\
104 \\
232\end{array}$ & $\begin{array}{r}4 \\
32 \\
36\end{array}$ & $\begin{array}{l}12 \\
22 \\
34\end{array}$ & $\begin{array}{l}3 \\
2 \\
5\end{array}$ & $\begin{array}{c}37 \star \\
2 \\
39\end{array}$ & $\begin{array}{l}16 \\
38 \\
54\end{array}$ \\
\hline $50 \%$ & $\begin{array}{l}4 A \\
4 B \\
\Sigma\end{array}$ & $\begin{array}{l}200 \\
200 \\
400\end{array}$ & $\begin{array}{l}103 \\
114 \\
217\end{array}$ & $\begin{array}{r}49 \\
5 \\
54\end{array}$ & $\begin{array}{l}22 \\
22 \\
44\end{array}$ & $\begin{array}{l}3 \\
4 \\
7\end{array}$ & $\begin{array}{l}1 \\
33^{\star} \\
34\end{array}$ & $\begin{array}{l}22 \\
22 \\
44\end{array}$ \\
\hline $75 \%$ & $\begin{array}{l}5 A \\
5 B \\
\Sigma\end{array}$ & $\begin{array}{l}200 \\
200 \\
400\end{array}$ & $\begin{array}{l}123 \\
105 \\
238\end{array}$ & $\begin{array}{l}15 \\
21 \\
36\end{array}$ & $\begin{array}{l}22 \\
22 \\
44\end{array}$ & $\begin{array}{l}21 \\
14 \\
35\end{array}$ & $\begin{array}{l}1 \\
7 \\
8\end{array}$ & $\begin{array}{l}18 \\
31 \\
49\end{array}$ \\
\hline $100 \star \star \star$ & $\begin{array}{c}3 A \\
3 B \\
\Sigma\end{array}$ & $\begin{array}{l}200 \\
200 \\
400 \\
\end{array}$ & $\begin{array}{l}116 \\
114 \\
230 \\
\end{array}$ & $\begin{array}{l}35 \\
34 \\
69 \\
\end{array}$ & $\begin{array}{r}22 \\
22 \\
44 \\
\end{array}$ & $\begin{array}{r}8 \\
11 \\
19 \\
\end{array}$ & $\begin{array}{l}0 \\
4 \\
4 \\
\end{array}$ & $\begin{array}{l}19 \\
15 \\
34 \\
\end{array}$ \\
\hline Totals & & 2400 & 1346 & 296 & 252 & 103 & 97 & 306 \\
\hline
\end{tabular}

* Mortalities occurred due plugged incoming water line.

* See text for a further explanation.

$\star \star \star$ The mean TRC concentration entering the $100 \%$ group was $0.034 \mathrm{mg} / 1$. 
TABLE 4. An Accounting of Rainbow Trout Mortalities During the Second Six Month Bioassay of Ch7orination By-Products.

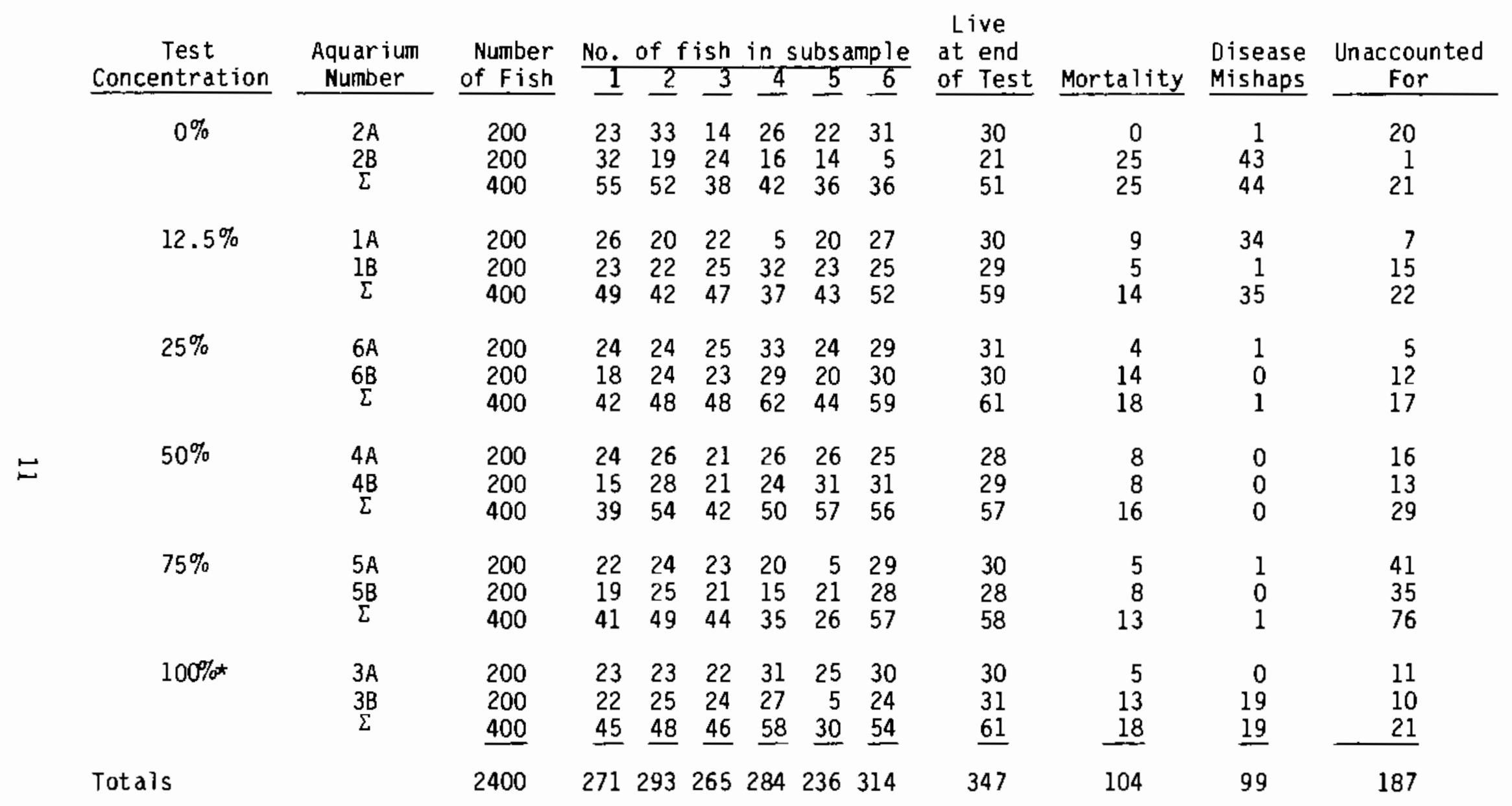

* See text for description of $100 \%$ test group. 
In the first test there were no significant differences in length (Table 5) or weight' (Table 6) between controls and other test levels at the end of 3 mo. Analys is of variance indicates a significant difference $(P=0.10)$ at 6 -mo between control and $50 \%$ and $75 \%$ groups (Table 7 ) in both length and weight. These fish were smaller in length and weight than the others. The $100 \%$ group was not significantly different from controls in either length or weight during the first test.

TABLE 5. Fork Lengths in Centimeters of Rainbow Trout Subsampled at 3 and 6 Months During the First Chronic Chlorination By-Product Test.

\begin{tabular}{|c|c|c|c|c|c|c|c|}
\hline \multirow{2}{*}{$\begin{array}{c}\text { Test } \\
\text { Concentration }\end{array}$} & \multirow{2}{*}{$\begin{array}{l}\text { Aquarium } \\
\text { Number }\end{array}$} & \multicolumn{3}{|c|}{3 Months } & \multicolumn{3}{|c|}{6 Months } \\
\hline & & $n$ & $\overline{\mathrm{x}}$ & $s$ & $n$ & $\bar{x}$ & 5 \\
\hline 0 & $\begin{array}{c}2 A \\
2 B \\
\Sigma\end{array}$ & $\begin{array}{l}104 \\
110 \\
214\end{array}$ & $\begin{array}{l}7.0 \\
7.3 \\
7.2\end{array}$ & $\begin{array}{l}1.1 \\
0.8 \\
1.0\end{array}$ & $\begin{array}{l}30 \\
33 \\
63\end{array}$ & $\begin{array}{l}8.9 \\
9.7 \\
9.4\end{array}$ & $\begin{array}{l}1.5 \\
1.5 \\
1.6\end{array}$ \\
\hline $12.5 \%$ & $\begin{array}{c}1 A \\
18 \\
\Sigma\end{array}$ & $\begin{array}{l}106 \\
118 \\
224\end{array}$ & $\begin{array}{l}7.2 \\
7.0 \\
7.1\end{array}$ & $\begin{array}{l}1.0 \\
0.8 \\
0.9\end{array}$ & $\begin{array}{l}27 \\
11 \\
38\end{array}$ & $\begin{array}{l}9.2 \\
8.8 \\
9.1\end{array}$ & $\begin{array}{l}1.2 \\
1.4 \\
1.3\end{array}$ \\
\hline $25 \%$ & $\begin{array}{c}6 \mathrm{~A} \\
6 \mathrm{~B} \\
\Sigma\end{array}$ & $\begin{array}{l}127 \\
103 \\
232\end{array}$ & $\begin{array}{l}7.0 \\
7.2 \\
7.1\end{array}$ & $\begin{array}{l}1.1 \\
1.0 \\
1.1\end{array}$ & $\begin{array}{r}4 \\
32 \\
36\end{array}$ & $\begin{array}{l}9.3 \\
8.8 \\
8.9\end{array}$ & $\begin{array}{l}1.5 \\
1.4 \\
1.4\end{array}$ \\
\hline $50 \%$ & $\begin{array}{c}4 A \\
4 B \\
\Sigma\end{array}$ & $\begin{array}{l}103 \\
114 \\
217\end{array}$ & $\begin{array}{l}7.1 \\
7.0 \\
7.0\end{array}$ & $\begin{array}{l}1.2 \\
1.0 \\
1.1\end{array}$ & $\begin{array}{r}49 \\
5 \\
54\end{array}$ & $\begin{array}{l}8.2 \\
8.3 \\
8.2\end{array}$ & $\begin{array}{l}1.0 \\
0.7 \\
1.0\end{array}$ \\
\hline $75 \%$ & $\begin{array}{l}5 A \\
5 B \\
\Sigma\end{array}$ & $\begin{array}{l}123 \\
105 \\
228\end{array}$ & $\begin{array}{l}7.0 \\
7.1 \\
7.0\end{array}$ & $\begin{array}{l}1.0 \\
1.2 \\
1.1\end{array}$ & $\begin{array}{l}15 \\
21 \\
36\end{array}$ & $\begin{array}{l}9.0 \\
8.0 \\
8.4\end{array}$ & $\begin{array}{l}1.1 \\
1.0 \\
1.1\end{array}$ \\
\hline $100 \%$ & $\begin{array}{l}3 A \\
3 B \\
\Sigma\end{array}$ & $\begin{array}{l}115 \\
114 \\
229\end{array}$ & $\begin{array}{l}7.0 \\
7.0 \\
7.0\end{array}$ & $\begin{array}{l}1.0 \\
1.0 \\
1.0\end{array}$ & $\begin{array}{l}35 \\
34 \\
69\end{array}$ & $\begin{array}{l}8.8 \\
8.8 \\
8.8\end{array}$ & $\begin{array}{l}1.1 \\
1.2 \\
1.3\end{array}$ \\
\hline Beginning & Bioassay & 20 & 4.4 & 0.37 & & & \\
\hline
\end{tabular}

$\Pi=$ Number of fish per sample.

$\bar{x}=$ Mean

$s=$ Standard Deviation 
TABLE 6. Weight in Grams of Rainbow Trout Subsampled at 3 and 6 Morths During the First Chronic Chlorination By-Product Test.

\begin{tabular}{|c|c|c|c|c|c|c|c|}
\hline \multirow[b]{2}{*}{$\begin{array}{c}\text { Test } \\
\text { Concentration } \\
\end{array}$} & \multirow[b]{2}{*}{$\begin{array}{l}\text { Aquarium } \\
\text { Number }\end{array}$} & \multicolumn{3}{|c|}{3 Months } & \multicolumn{3}{|c|}{6 Months } \\
\hline & & $n$ & $\bar{x}$ & 5 & $\mathrm{n}$ & $\bar{x}$ & $s$ \\
\hline 0 & $\begin{array}{l}2 \mathrm{~A} \\
2 \mathrm{~B} \\
\Sigma\end{array}$ & $\begin{array}{l}104 \\
110 \\
214\end{array}$ & $\begin{array}{l}4.61 \\
4.95 \\
4.87\end{array}$ & $\begin{array}{l}2.29 \\
1.74 \\
1.81\end{array}$ & $\begin{array}{l}30 \\
33 \\
63\end{array}$ & $\begin{array}{r}9.98 \\
11.61 \\
11.90\end{array}$ & $\begin{array}{l}6.00 \\
6.05 \\
6.18\end{array}$ \\
\hline $12.5 \%$ & $\begin{array}{c}1 \mathrm{~A} \\
1 \mathrm{~B} \\
\Sigma\end{array}$ & $\begin{array}{l}106 \\
118 \\
224\end{array}$ & $\begin{array}{l}4: 72 \\
4.48 \\
4.59\end{array}$ & $\begin{array}{l}1.87 \\
1.71 \\
1.79\end{array}$ & $\begin{array}{l}27 \\
11 \\
38\end{array}$ & $\begin{array}{r}10.44 \\
9.51 \\
10.17\end{array}$ & $\begin{array}{r}4.66 \\
4.75 \\
4.64\end{array}$ \\
\hline $25 \%$ & $\begin{array}{c}6 \mathrm{~A} \\
6 \mathrm{~B} \\
\Sigma\end{array}$ & $\begin{array}{l}128 \\
104 \\
232\end{array}$ & $\begin{array}{l}4.50 \\
4.78 \\
4.62\end{array}$ & $\begin{array}{l}2.15 \\
2.09 \\
2.12\end{array}$ & $\begin{array}{r}4 \\
32 \\
36\end{array}$ & $\begin{array}{r}12.18 \\
9.70 \\
9.98\end{array}$ & $\begin{array}{l}6.58 \\
4.57 \\
4.78\end{array}$ \\
\hline $50 \%$ & $\begin{array}{c}4 A \\
4 B \\
\Sigma\end{array}$ & $\begin{array}{l}103 \\
114 \\
217\end{array}$ & $\begin{array}{l}4.74 \\
4.64 \\
4.63\end{array}$ & $\begin{array}{l}2.79 \\
2.70 \\
2.38\end{array}$ & $\begin{array}{r}49 \\
5 \\
54\end{array}$ & $\begin{array}{l}7.84 \\
8.43 \\
7.89\end{array}$ & $\begin{array}{l}3.03 \\
2.50 \\
2.97\end{array}$ \\
\hline $75 \%$ & $\begin{array}{c}5 A \\
5 B \\
\Sigma\end{array}$ & $\begin{array}{l}123 \\
105 \\
228\end{array}$ & $\begin{array}{l}4.51 \\
4.53 \\
4.52\end{array}$ & $\begin{array}{l}2.02 \\
2.31 \\
2.15\end{array}$ & $\begin{array}{l}15 \\
21 \\
36\end{array}$ & $\begin{array}{r}10.28 \\
7.01 \\
8.37\end{array}$ & $\begin{array}{l}4.07 \\
2.87 \\
3.74\end{array}$ \\
\hline $100 \%$ & $\begin{array}{c}3 A \\
3 B \\
\Sigma\end{array}$ & $\begin{array}{l}115 \\
114 \\
229\end{array}$ & $\begin{array}{l}4.42 \\
4.43 \\
4.43\end{array}$ & $\begin{array}{l}2.17 \\
1.86 \\
2.02\end{array}$ & $\begin{array}{l}35 \\
34 \\
69\end{array}$ & $\begin{array}{l}9.82 \\
9.61 \\
9.72\end{array}$ & $\begin{array}{l}4.63 \\
4.16 \\
4.37\end{array}$ \\
\hline
\end{tabular}

\footnotetext{
$n=$ Number of $f$ ish per subs ample

$\overline{\mathrm{x}}=$ Mean

$\mathrm{s}=$ Standard Deviation
} 
TABLE 7. Data Summary of Growth Data at the 6 Month Sampling in the First Chronic Chlorination By-Product Test.

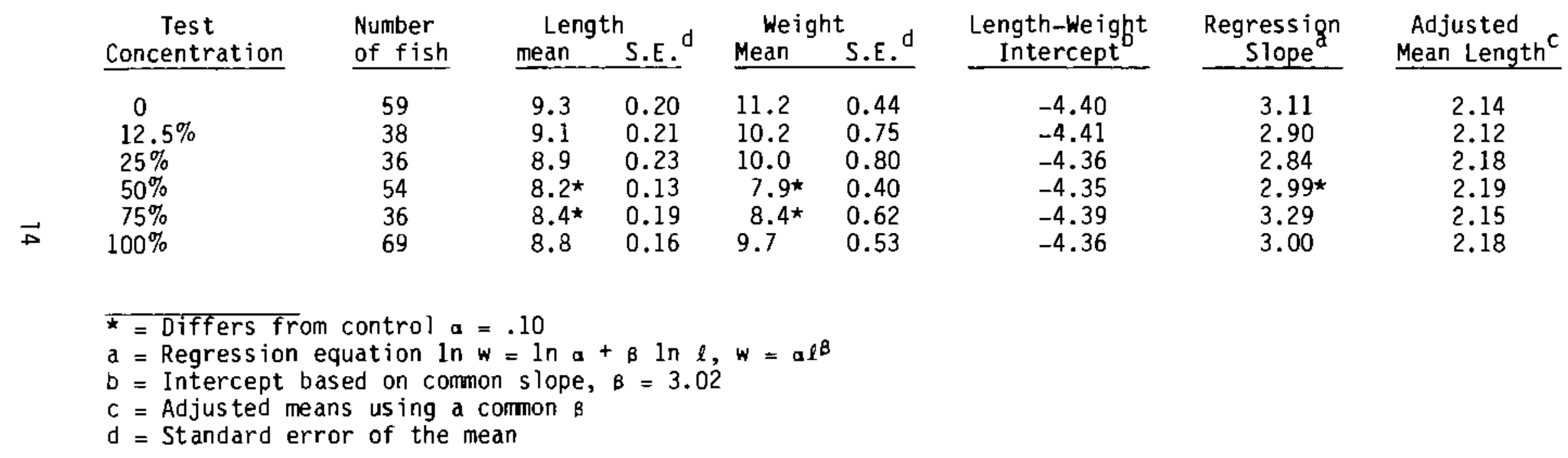


Coefficient of condition or condition factor was computed at each subsampling (Table 8 ). This length (L) weight $(w)$ relationship $\left(w / L^{3}\right.$ ) was expressed the regression $l n w=\ln a+B \ln \mathrm{L}$ where $\beta$ is the slope and $l n a$ is the lengthweight intercept (Table 7). Analysis of covariance of length-weight relationship indicated no significant difference in slope ( $\beta$ ) between control and test groups. Analys is of the adjusted means adjusted to the common slope ( $\beta=3.02$ ) indicates a significant difference between the control and the $50 \%$ test group. When compared to the control, none of the other test groups differed significantly using the procedures by Dunnett (1964). Condition factors are used as an estimate of the overali health of $f$ ish of the same age and species and are related to the general growth formula in that condition factors assume a cubic

TABLE 8. Condition Factor of Rainbow Trout Subsampled at 3 and 6 Months During the First Chronic Chlorination By-Product Test.

\begin{tabular}{|c|c|c|c|c|c|}
\hline \multirow{2}{*}{$\begin{array}{l}\text { Test } \\
\text { Group }\end{array}$} & \multirow{2}{*}{$\begin{array}{l}\text { Aquar ium } \\
\text { Number }\end{array}$} & \multicolumn{2}{|c|}{3 Months } & \multicolumn{2}{|c|}{6 Months } \\
\hline & & $n$ & $\bar{x}$ & $n$ & $\bar{x}$ \\
\hline 0 & $\begin{array}{c}2 \mathrm{~A} \\
2 \mathrm{~B} \\
\Sigma\end{array}$ & $\begin{array}{l}104 \\
110 \\
214\end{array}$ & $\begin{array}{l}1.227 \\
1.201 \\
1.214\end{array}$ & $\begin{array}{l}30 \\
33 \\
63\end{array}$ & $\begin{array}{l}1.274 \\
1.316 \\
1.296\end{array}$ \\
\hline $12.5 \%$ & $\begin{array}{c}1 \mathrm{~A} \\
1 \mathrm{~B} \\
\Sigma\end{array}$ & $\begin{array}{l}106 \\
118 \\
224\end{array}$ & $\begin{array}{l}1.212 \\
1.233 \\
1.223\end{array}$ & $\begin{array}{l}27 \\
11 \\
38\end{array}$ & $\begin{array}{l}1.270 \\
1.318 \\
1.284\end{array}$ \\
\hline $25 \%$ & $\begin{array}{l}6 \mathrm{~A} \\
6 \mathrm{~B}\end{array}$ & $\begin{array}{l}127 \\
103 \\
232\end{array}$ & $\begin{array}{l}1.231 \\
1.221 \\
1.216\end{array}$ & $\begin{array}{r}4 \\
32 \\
36\end{array}$ & $\begin{array}{l}1.407 \\
1.343 \\
1.350\end{array}$ \\
\hline $50 \%$ & $\begin{array}{c}4 A \\
4 B \\
\Sigma\end{array}$ & $\begin{array}{l}103 \\
114 \\
217\end{array}$ & $\begin{array}{l}1.231 \\
1.327 \\
1.235\end{array}$ & $\begin{array}{r}49 \\
5 \\
54\end{array}$ & $\begin{array}{l}1.352 \\
1.431 \\
1.360\end{array}$ \\
\hline $75 \%$ & $\begin{array}{c}5 A \\
5 B \\
\Sigma\end{array}$ & $\begin{array}{l}123 \\
105 \\
228\end{array}$ & $\begin{array}{l}1.220 \\
1.181 \\
1.202\end{array}$ & $\begin{array}{l}15 \\
21 \\
36\end{array}$ & $\begin{array}{l}1.362 \\
1.274 \\
1.311\end{array}$ \\
\hline $100 \%$ & $\begin{array}{c}3 \mathrm{~A} \\
3 \mathrm{~B} \\
\Sigma\end{array}$ & $\begin{array}{l}115 \\
114 \\
229\end{array}$ & $\begin{array}{l}1.232 \\
1.216 \\
1.224\end{array}$ & $\begin{array}{l}35 \\
34 \\
69\end{array}$ & $\begin{array}{l}1.343 \\
1.354 \\
1.349\end{array}$ \\
\hline
\end{tabular}

$\underline{n}=$ Number of fish per subsample

$\bar{x}=$ Mean 
relationship between length and weight. The growth formula utilizes the measurements of length and weight to then define the relationship mathematically $(B)$. Condition factors are not applicable to all species of fish if the cubic length-weight relationship is not valid. The results (Table 7) demonstrate that a cubic $(B=3.02)$ length-wejght relationship exists and the condition factor is appropriate to trout in these tests. The statistically significant difference between the $50 \%$ group and controls indicates the controls were in better condition than the $50 \%$ group. This was corroborated also by the length and weight differences between control and the $50 \%$ group.

Differences in condition factor and between control and test groups may be influenced by several factors including fish density as well as TRC or chlorination by-product concentration. Aquaria $6 \mathrm{~A}$ and $4 \mathrm{~B}$ in the $25 \%$ and $50 \%$ test groups, respectively, had the lowest fish densities, as a result of disease outbreak, and the highest condition factors. The observed difference in the $50 \%$ test group is not judged to be a result of exposure to TRC or chlorination by-products.

Results of morphological measurements of fish from each subsample in the second test are given in Tables 9, 10 and 11. Comparison between test groups for each subsample reveals little difference in mean and range for fork length, weight and condition factor at each subsample. An increase in both length and weight with time was found, as expected. Since condition factor is only useful to indicate an effect on juvenile fish of the same age, comparisons of condition factors are not valid as an indication of an effect of test concentration for fish of different ages.

Based on the different approach in chlorination between the two tests, a comparison of the mean TRC levels between the two tests is not meaningful. During the second test TRC levels in the $100 \%$ test group were $<0.001 \mathrm{ppm}$ TRC at some times during the test, whereas during the first test a chlorine residual was always maintained.

Even though the basic approaches to both tests were different the results of both tests confirmed that there was no effect on growth or mortality resulting from chlorination by-product toxicity. Nevertheless, an effect on the health of the test fish as indicated by condition factor was found. 
TABLE 9. Fork Length in Centimeters of Rainbow Trout During the 2nd ChTorination By-Product Bioassay.

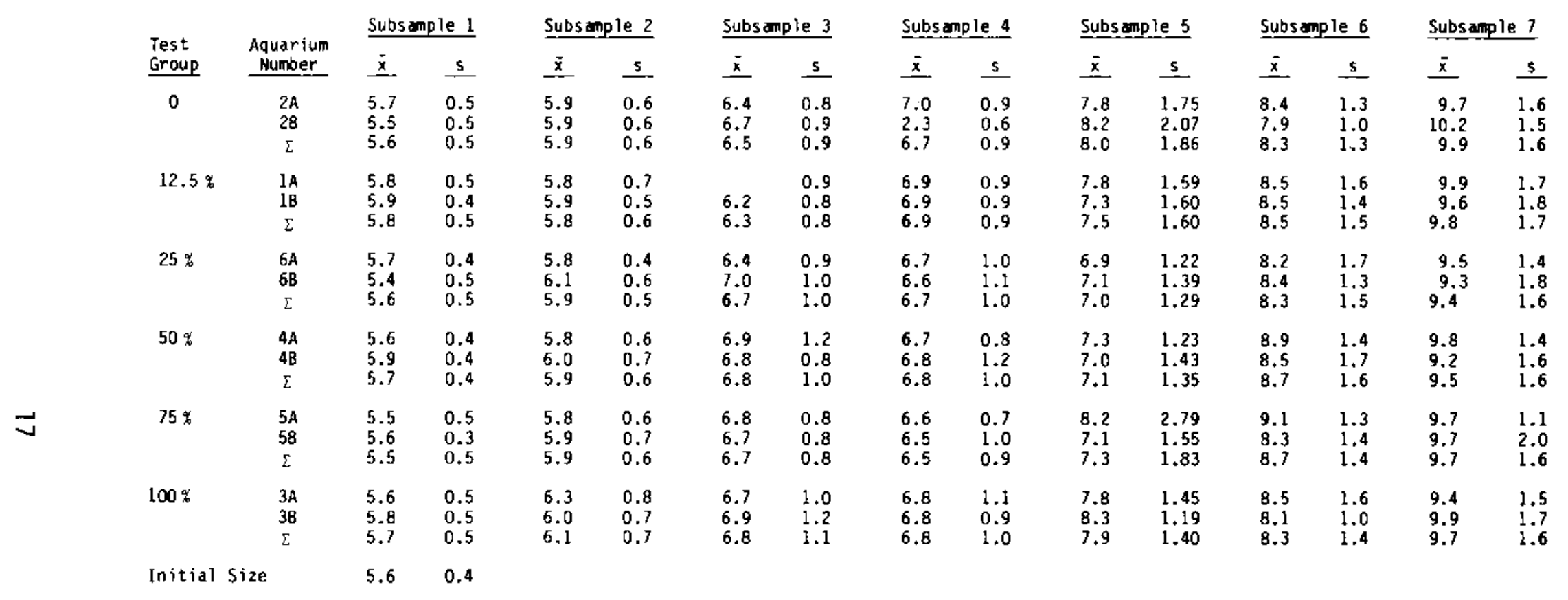


TABLE 10. Weight in Grams of Rainbow Trout During the 2nd Chlorination By-Product Bioassay

\begin{tabular}{|c|c|c|c|c|c|c|c|c|c|c|c|c|c|c|c|}
\hline & \multirow{2}{*}{$\begin{array}{l}\text { Aquaríum } \\
\text { Number }\end{array}$} & \multicolumn{2}{|c|}{ Subsample 1} & \multicolumn{2}{|c|}{ Subsample 2} & \multicolumn{2}{|c|}{ Subsample 3} & \multicolumn{2}{|c|}{$\underline{\text { Subs ample } 4}$} & \multicolumn{2}{|c|}{ Subsample 5} & \multicolumn{2}{|c|}{ Subs ample 6} & \multicolumn{2}{|c|}{ Subsample 7} \\
\hline $\begin{array}{l}\text { Group } \\
\text { Group }\end{array}$ & & $\underline{\bar{x}}$ & $\underline{s}$ & $\underline{\bar{x}}$ & $s$ & $\underline{\bar{x}}$ & $s$ & $\overline{\bar{x}}$ & $s$ & $\underline{\bar{x}}$ & 5 & $\underline{\bar{x}}$ & $s$ & $\underline{x}$ & $s$ \\
\hline 0 & $\begin{array}{c}2 \mathrm{~A} \\
2 \mathrm{~B} \\
\Sigma\end{array}$ & $\begin{array}{l}2.44 \\
2.20 \\
2.30\end{array}$ & $\begin{array}{l}0.79 \\
0.66 \\
0.72\end{array}$ & $\begin{array}{l}2.53 \\
2.45 \\
2.50\end{array}$ & $\begin{array}{l}0.87 \\
1.04 \\
0.93\end{array}$ & $\begin{array}{l}3.18 \\
3.49 \\
3.34\end{array}$ & $\begin{array}{l}1.19 \\
1.69 \\
1.47\end{array}$ & $\begin{array}{l}4.40 \\
3.09 \\
3.90\end{array}$ & $\begin{array}{l}1.93 \\
1.21 \\
1.80\end{array}$ & $\begin{array}{l}7.37 \\
8.38 \\
7.76\end{array}$ & $\begin{array}{l}5.73 \\
6.23 \\
5.86\end{array}$ & $\begin{array}{l}8.61 \\
7.92 \\
8.51\end{array}$ & $\begin{array}{l}4.32 \\
3.21 \\
4.15\end{array}$ & $\begin{array}{l}12.88 \\
14.24 \\
13.44\end{array}$ & $\begin{array}{l}6.18 \\
6.51 \\
6.29\end{array}$ \\
\hline $12.5 \%$ & $\begin{array}{l}1 A \\
1 B \\
\Sigma\end{array}$ & $\begin{array}{l}2.20 \\
2.57 \\
2.38\end{array}$ & $\begin{array}{l}0.76 \\
0.68 \\
0.74\end{array}$ & $\begin{array}{l}2.43 \\
2.39 \\
2.41\end{array}$ & $\begin{array}{l}1.18 \\
0.67 \\
0.94\end{array}$ & $\begin{array}{l}3.25 \\
2.99 \\
3.08\end{array}$ & $\begin{array}{l}1.68 \\
1.29 \\
1.43\end{array}$ & $\begin{array}{l}4.22 \\
4.11 \\
4.12\end{array}$ & $\begin{array}{l}1.85 \\
1.87 \\
1.84\end{array}$ & $\begin{array}{l}6.64 \\
5.93 \\
6.26\end{array}$ & $\begin{array}{l}3.78 \\
4.42 \\
4.10\end{array}$ & $\begin{array}{l}9.42 \\
8.76 \\
9.08\end{array}$ & $\begin{array}{l}5.48 \\
4.27 \\
4.86\end{array}$ & $\begin{array}{l}13.26 \\
12.66 \\
12.96\end{array}$ & $\begin{array}{l}6.67 \\
7.18 \\
6.87\end{array}$ \\
\hline $25 \%$ & $\begin{array}{c}6 \mathrm{~A} \\
6 \mathrm{~B} \\
\Sigma\end{array}$ & $\begin{array}{l}2.42 \\
1.92 \\
2.20\end{array}$ & $\begin{array}{l}0.67 \\
0.55 \\
0.66\end{array}$ & $\begin{array}{l}2.48 \\
2.86 \\
2.67\end{array}$ & $\begin{array}{l}0.67 \\
1.08 \\
0.90\end{array}$ & $\begin{array}{l}3.21 \\
4.28 \\
3.76\end{array}$ & $\begin{array}{l}1.35 \\
2.00 \\
1.78\end{array}$ & $\begin{array}{l}4.49 \\
4.42 \\
4.46\end{array}$ & $\begin{array}{l}2.29 \\
2.53 \\
2.38\end{array}$ & $\begin{array}{l}5.01 \\
5.60 \\
5.28\end{array}$ & $\begin{array}{l}3.33 \\
3.85 \\
3.54\end{array}$ & $\begin{array}{l}8.95 \\
9.53 \\
9.25\end{array}$ & $\begin{array}{l}5.71 \\
4.25 \\
4.97\end{array}$ & $\begin{array}{l}12.58 \\
12.41 \\
12.50\end{array}$ & $\begin{array}{l}5.80 \\
7.62 \\
6.70\end{array}$ \\
\hline $50 \%$ & $\begin{array}{l}4 A \\
4 B \\
\Sigma\end{array}$ & $\begin{array}{l}2.19 \\
2.56 \\
2.34\end{array}$ & $\begin{array}{l}0.57 \\
0.58 \\
0.60\end{array}$ & $\begin{array}{l}2.47 \\
2.95 \\
2.72\end{array}$ & $\begin{array}{l}0.79 \\
1.53 \\
1.24\end{array}$ & $\begin{array}{l}4.22 \\
3.89 \\
4.06\end{array}$ & $\begin{array}{l}2.83 \\
1.49 \\
2.24\end{array}$ & $\begin{array}{l}4.39 \\
5.02 \\
4.69\end{array}$ & $\begin{array}{l}1.86 \\
3.28 \\
2.63\end{array}$ & $\begin{array}{l}5.83 \\
5.56 \\
5.68\end{array}$ & $\begin{array}{l}2.91 \\
4.13 \\
3.60\end{array}$ & $\begin{array}{r}10.38 \\
9.44 \\
9.87\end{array}$ & $\begin{array}{l}5.55 \\
5.52 \\
5.50\end{array}$ & $\begin{array}{l}13.98 \\
11.85 \\
12.90\end{array}$ & $\begin{array}{l}8.85 \\
6.60 \\
7.79\end{array}$ \\
\hline $75 \%$ & $\begin{array}{c}5 A \\
5 B \\
\Sigma\end{array}$ & $\begin{array}{l}2.06 \\
2.12 \\
2.09\end{array}$ & $\begin{array}{l}0.84 \\
0.36 \\
0.66\end{array}$ & $\begin{array}{l}2.42 \\
2.74 \\
2.58\end{array}$ & $\begin{array}{l}0.80 \\
1.20 \\
1.02\end{array}$ & $\begin{array}{l}3.79 \\
3.62 \\
3.71\end{array}$ & $\begin{array}{l}1.44 \\
1.40 \\
1.41\end{array}$ & $\begin{array}{l}4.08 \\
4.00 \\
4.04\end{array}$ & $\begin{array}{l}1.50 \\
1.95 \\
1.68\end{array}$ & $\begin{array}{l}7.36 \\
6.07 \\
6.32\end{array}$ & $\begin{array}{l}4.99 \\
5.86 \\
5.63\end{array}$ & $\begin{array}{r}11.36 \\
8.96 \\
10.18\end{array}$ & $\begin{array}{l}4.63 \\
4.39 \\
4.63\end{array}$ & $\begin{array}{l}12.59 \\
13.79 \\
13.22\end{array}$ & $\begin{array}{l}4.05 \\
8.86 \\
6.77\end{array}$ \\
\hline $100 \%$ & $\begin{array}{c}3 A \\
3 B \\
E\end{array}$ & $\begin{array}{l}2.79 \\
2.43 \\
2.61\end{array}$ & $\begin{array}{l}2.01 \\
0.78 \\
1.53\end{array}$ & $\begin{array}{l}3.13 \\
2.70 \\
2.90\end{array}$ & $\begin{array}{l}1.27 \\
1.13 \\
1.22\end{array}$ & $\begin{array}{l}3.90 \\
4.34 \\
4.11\end{array}$ & $\begin{array}{l}1.95 \\
2.72 \\
2.33\end{array}$ & $\begin{array}{l}4.21 \\
4.77 \\
4.47\end{array}$ & $\begin{array}{l}2.33 \\
2.37 \\
2.34\end{array}$ & $\begin{array}{l}7.12 \\
8.27 \\
7.31\end{array}$ & $\begin{array}{l}3.95 \\
3.29 \\
3.82\end{array}$ & $\begin{array}{l}8.90 \\
7.42 \\
8.24\end{array}$ & $\begin{array}{l}5.51 \\
2.70 \\
4.51\end{array}$ & $\begin{array}{l}11.72 \\
14.17 \\
12.96\end{array}$ & $\begin{array}{l}6.44 \\
7.22 \\
6.90\end{array}$ \\
\hline Initial & Size & 1.67 & 0.40 & & & & & & & & & & & & \\
\hline
\end{tabular}

$\bar{x}=$ mean

$s$ = standard deviation 
TABLE 11. Condition Factors ${ }^{a}$ for Rainbow Trout During the 2nd Chlorination By-Product Bioassay.

\begin{tabular}{|c|c|c|c|c|c|c|c|c|c|c|c|c|c|c|c|c|}
\hline & \multirow{2}{*}{$\begin{array}{l}\text { Test } \\
\text { Group }\end{array}$} & \multirow{2}{*}{$\begin{array}{l}\text { Aquarium } \\
\text { Number }\end{array}$} & \multicolumn{2}{|c|}{ Subs ample 1} & \multicolumn{2}{|c|}{ Subsample? } & \multicolumn{2}{|c|}{ Subs ample 3} & \multicolumn{2}{|c|}{ Subs ample 4} & \multicolumn{2}{|c|}{ Subsample 5} & \multicolumn{2}{|c|}{ Subs ample 6} & \multicolumn{2}{|c|}{ Subs anple 7} \\
\hline & & & $\bar{x}$ & 5 & $\bar{x}$ & $s$ & $\bar{x}$ & $s$ & $\bar{x}$ & $s$ & $\underline{x}$ & $s$ & $\underline{\bar{x}}$ & $s$ & $\bar{x}$ & $\$$ \\
\hline & 0 & $\begin{array}{c}2 A \\
2 B \\
\Sigma\end{array}$ & $\begin{array}{l}1.26 \\
1.26 \\
1.26\end{array}$ & $\begin{array}{l}0.08 \\
0.09 \\
0.86\end{array}$ & $\begin{array}{l}1.20 \\
1.16 \\
1.18\end{array}$ & $\begin{array}{l}0.14 \\
0.12 \\
0.13\end{array}$ & $\begin{array}{l}1.18 \\
1.10 \\
1.14\end{array}$ & $\begin{array}{l}0.06 \\
0.09 \\
0.09\end{array}$ & $\begin{array}{l}1.23 \\
1.20 \\
1.21\end{array}$ & $\begin{array}{l}0.09 \\
0.14 \\
0.11\end{array}$ & $\begin{array}{l}1.32 \\
1.31 \\
1.32\end{array}$ & $\begin{array}{l}0.08 \\
0.12 \\
0.09\end{array}$ & $\begin{array}{l}1.37 \\
1.54 \\
1.39\end{array}$ & $\begin{array}{l}0.08 \\
0.29 \\
0.14\end{array}$ & $\begin{array}{l}1.32 \\
1.29 \\
1.31\end{array}$ & $\begin{array}{l}0.13 \\
0.06 \\
0.10\end{array}$ \\
\hline & $12.5 \%$ & $\begin{array}{c}1 \mathrm{~A} \\
1 \mathrm{~B} \\
\Sigma\end{array}$ & $\begin{array}{l}1.10 \\
1.30 \\
1.19\end{array}$ & $\begin{array}{l}0.13 \\
0.10 \\
0.15\end{array}$ & $\begin{array}{l}1.13 \\
1.17 \\
1.15\end{array}$ & $\begin{array}{l}0.14 \\
0.11 \\
0.12\end{array}$ & $\begin{array}{l}1.13 \\
1.21 \\
1.18\end{array}$ & $\begin{array}{l}0.06 \\
0.10 \\
0.09\end{array}$ & $\begin{array}{l}1.21 \\
1.19 \\
0.19\end{array}$ & $\begin{array}{l}0.10 \\
0.10 \\
0.10\end{array}$ & $\begin{array}{l}1.28 \\
1.30 \\
1.29\end{array}$ & $\begin{array}{l}0.15 \\
0.13 \\
0.14\end{array}$ & $\begin{array}{l}1.37 \\
1.32 \\
1.34\end{array}$ & $\begin{array}{l}0.12 \\
0.12 \\
0.12\end{array}$ & $\begin{array}{l}1.27 \\
1.30 \\
1.28\end{array}$ & $\begin{array}{l}0.09 \\
0.20 \\
0.15\end{array}$ \\
\hline & $25 \%$ & $\begin{array}{c}6 A \\
6 B \\
\Sigma\end{array}$ & $\begin{array}{l}1.25 \\
1.19 \\
1.22\end{array}$ & $\begin{array}{l}0.11 \\
0.10 \\
0.11\end{array}$ & $\begin{array}{l}1.22 \\
1.23 \\
1.23\end{array}$ & $\begin{array}{l}0.09 \\
0.10 \\
0.09\end{array}$ & $\begin{array}{l}1.13 \\
1.17 \\
1.15\end{array}$ & $\begin{array}{l}0.10 \\
0.07 \\
0.08\end{array}$ & $\begin{array}{l}1.39 \\
1.38 \\
1.39\end{array}$ & $\begin{array}{l}0.17 \\
0.15 \\
0.16\end{array}$ & $\begin{array}{l}1.34 \\
1.40 \\
1.36\end{array}$ & $\begin{array}{l}0.17 \\
0.11 \\
0.15\end{array}$ & $\begin{array}{l}1.41 \\
1.47 \\
1.44\end{array}$ & $\begin{array}{l}0.16 \\
0.14 \\
0.15\end{array}$ & $\begin{array}{l}1.37 \\
1.40 \\
1.39\end{array}$ & $\begin{array}{l}0.09 \\
0.10 \\
0.09\end{array}$ \\
\hline & $50 \%$ & $\begin{array}{c}4 A \\
4 B \\
\Sigma\end{array}$ & $\begin{array}{l}1.25 \\
1.23 \\
1.24\end{array}$ & $\begin{array}{l}0.13 \\
0.07 \\
0.11\end{array}$ & $\begin{array}{l}1.20 \\
1.26 \\
1.23\end{array}$ & $\begin{array}{l}0.07 \\
0.17 \\
0.10\end{array}$ & $\begin{array}{l}1.17 \\
1.17 \\
1.17\end{array}$ & $\begin{array}{l}0.09 \\
0.05 \\
0.07\end{array}$ & $\begin{array}{l}1.36 \\
1.46 \\
1.41\end{array}$ & $\begin{array}{l}0.10 \\
0.13 \\
0.13\end{array}$ & $\begin{array}{l}1.40 \\
1.44 \\
1.42\end{array}$ & $\begin{array}{l}0.14 \\
0.22 \\
0.19\end{array}$ & $\begin{array}{l}3.35 \\
1.37 \\
1.36\end{array}$ & $\begin{array}{l}0.15 \\
0.13 \\
0.14\end{array}$ & $\begin{array}{l}1.37 \\
1.38 \\
1.37\end{array}$ & $\begin{array}{l}0.09 \\
0.10 \\
0.10\end{array}$ \\
\hline $\overrightarrow{0}$ & $75 \%$ & $\begin{array}{c}5 A \\
5 B \\
\Sigma\end{array}$ & $\begin{array}{l}1.19 \\
1.21 \\
1.20\end{array}$ & $\begin{array}{l}0.12 \\
0.12 \\
0.12\end{array}$ & $\begin{array}{l}1.19 \\
1.25 \\
1.22\end{array}$ & $\begin{array}{l}0.10 \\
0.20 \\
0.16\end{array}$ & $\begin{array}{l}1.16 \\
1.17 \\
1.16\end{array}$ & $\begin{array}{l}0.09 \\
0.08 \\
0.09\end{array}$ & $\begin{array}{l}1.39 \\
1.37 \\
1.38\end{array}$ & $\begin{array}{l}0.11 \\
0.17 \\
0.14\end{array}$ & $\begin{array}{l}1.32 \\
1.42 \\
1.40\end{array}$ & $\begin{array}{l}0.38 \\
0.12 \\
0.19\end{array}$ & $\begin{array}{l}1.44 \\
i .43 \\
1.44\end{array}$ & $\begin{array}{l}0.10 \\
0.12 \\
0.11\end{array}$ & $\begin{array}{l}1.34 \\
1.31 \\
1.33\end{array}$ & $\begin{array}{l}0.06 \\
0.08 \\
0.07\end{array}$ \\
\hline & $100 \%$ & $\begin{array}{c}3 \mathrm{~A} \\
3 \mathrm{~B} \\
\Sigma\end{array}$ & $\begin{array}{l}1.70 \\
1.22 \\
1.46\end{array}$ & $\begin{array}{l}1.88 \\
0.12 \\
1.35\end{array}$ & $\begin{array}{l}1.19 \\
1.22 \\
1.21\end{array}$ & $\begin{array}{l}0.13 \\
0.11 \\
0.12\end{array}$ & $\begin{array}{l}1.18 \\
1.18 \\
1.18\end{array}$ & $\begin{array}{l}0.08 \\
0.09 \\
0.08\end{array}$ & $\begin{array}{l}1.20 \\
1.42 \\
1.30\end{array}$ & $\begin{array}{l}0.12 \\
0.17 \\
0.18\end{array}$ & $\begin{array}{l}1.35 \\
1.42 \\
1.36\end{array}$ & $\begin{array}{l}0.10 \\
0.12 \\
0.11\end{array}$ & $\begin{array}{l}1.32 \\
1.34 \\
1.33\end{array}$ & $\begin{array}{l}0.10 \\
0.10 \\
0.10\end{array}$ & $\begin{array}{l}1.33 \\
1.32 \\
1.32\end{array}$ & $\begin{array}{l}0.07 \\
0.08 \\
0.07\end{array}$ \\
\hline & Initial & ize & 1.08 & 0.09 & & & & & & & & & & & & \\
\hline & ${ }^{a}$ Condi & of $f$ ish & $\frac{W}{\ell} 3$ & & & & & & & & & & & & & \\
\hline
\end{tabular}


Analys is of Tissues for Organoch lor ine Compounds

Results of chloroform analyses in fish tissue are summarized in Table 12. Chloroform was found in the tissues, but no difference was noted between exposed and control fish. The absence of a difference in levels between the two groups is not surprising considering the chloroform level in the control aquarium water was approximately one quarter the level found in the treated water. The identity and concentrations of chloroform in the tissues of exposed fishes was confirmed by GC/MS.

Chloroform found in tissue of fish demonstrate that low levels of chloroform in water are accumulated by fish. Since chloroform is Tipophilic it will concentrate in tissues with a high lipid content. Preliminary tests with chloroform accumulation in various fish tissues substantiated this (Anderson and Lusty, 1980). Muscle tissue with a correspondingly low lipid content does not accumplate as much chioroform relative to gonadal and fatty tissues such as fat serrounding the gut and pyloric caeca. Thus, the chloroform concentration in fish tissue (Table 12) which is expressed in terms of total weight underestimates the chloroform concentration in the fatty tissues although the results provide comparative values for chloroform content in whole fish. Concentration of chloroform in tissues of high lipid content could effect fish reproduction and behavior and thus warrants further investigation.

TABLE 12. Estimated Chloroform in Rainbow Trout Tissue.

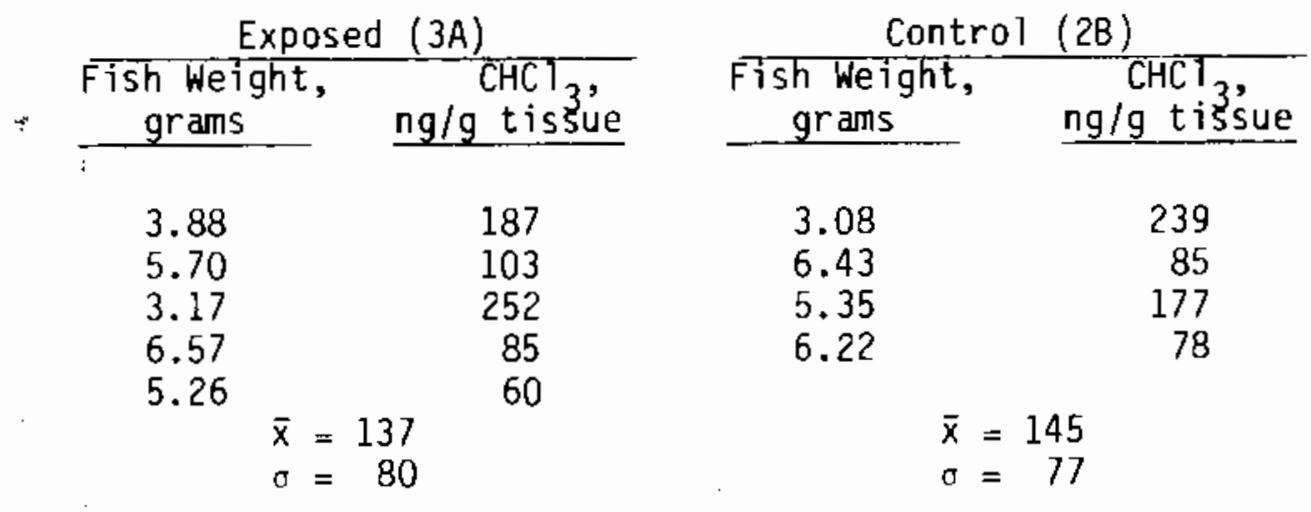


Results of the nonvolatile residue and total chlorine in the crude tissue extracts are presented in Table 13. Significantly less nonvolatile residue was extracted from the exposed fish than from the controls ( $P<0.05$ with a $t$ test). Although the differences are statistically significant, it has not been determined whether they are treatment related effects or simply deviations resulting from the small subsample size used in the analys is. There was no reason to expect chlorination by-products to reduce nonvolatile residue. A significant amount of chlorine was also present in the second extraction, suggesting that longer extraction times or more polar solvents should be used to extract these tissues. Another possibility that must be considered when reviewing the chlorine data is that the measured levels are biased high by interference from other sample components. Interference from the sample solvent has been observed and the data have been corrected for this effect. Large quantities of nitrogen or sulfur in the sample might also cause positive interference. A laboratory evaluation of possible interferences should be made since reliable information on interfering substances is not available.

TABLE 13. Characterization of Crude Extracts of Fish Tissues from the First Bioassay.

1st Extraction:

Nonvolatile residue, $\mathrm{mg} / \mathrm{g}$ tissue

Total Chlorine, $\mu g / g$ tissue ${ }^{a}$

Total Chlorine after drying and Control Exposed

reconstituting, $\mu \mathrm{g} / \mathrm{g}$ tissue

\section{2nd Extraction:}

Nonvolatile residue, $\mathrm{mg} / \mathrm{g}$

Total Chlorine, $\mu \mathrm{g} / \mathrm{g}$ tissue

Sum of 1st and 2nd Extraction:

Nonvolatile residue, $\mathrm{mg} / \mathrm{g}$ tissue

$257.6 \quad 144.8$

Total Chlorine, $\mu g / g$ tissue

a Values are averages of four replicate determinations and are corrected for the solvent blank. The standard deviation for the chlorine measurements is estimated to be $7 \mu \mathrm{g} / \mathrm{g}$ tissue. Organic and inorganic chlorine are included in these measurements. 
Results of tissue analyses are summarized in Figure $3 A$ and $B$ for control and exposed $\mathrm{fish}$, respectively. Most extracted solids elute in the early fractions (2-6) and thus are of relatively high molecular weight. Recoveries of the sample by suming the weights of the residues in the column cuts from the column were estimated to be $104 \%$ and $70 \%$ for exposed and control fish, respectively. Fractions 3-7 show significant absorbance at $270 \mathrm{~nm}$ ( $\lambda$ MAX), indicative of aromatic compounds. These compounds should be lipophilic substances of intermediate molecular weight.

Selected fractions were concentrated by evaporating the dichloromethane and taking the residues up in $200 \mu l$ of benzene (Burdick-Jackson) ${ }^{\circ}$. Benzene solutions were chromatographed on a 30M OV-101 glass capillary column programed from $40^{\circ} \mathrm{C}$ to $230^{\circ} \mathrm{C}$ using an electron capture detector. Peaks observed in the chromatograms of fractions from exposed fish were also present in chromatograms of the controls. 

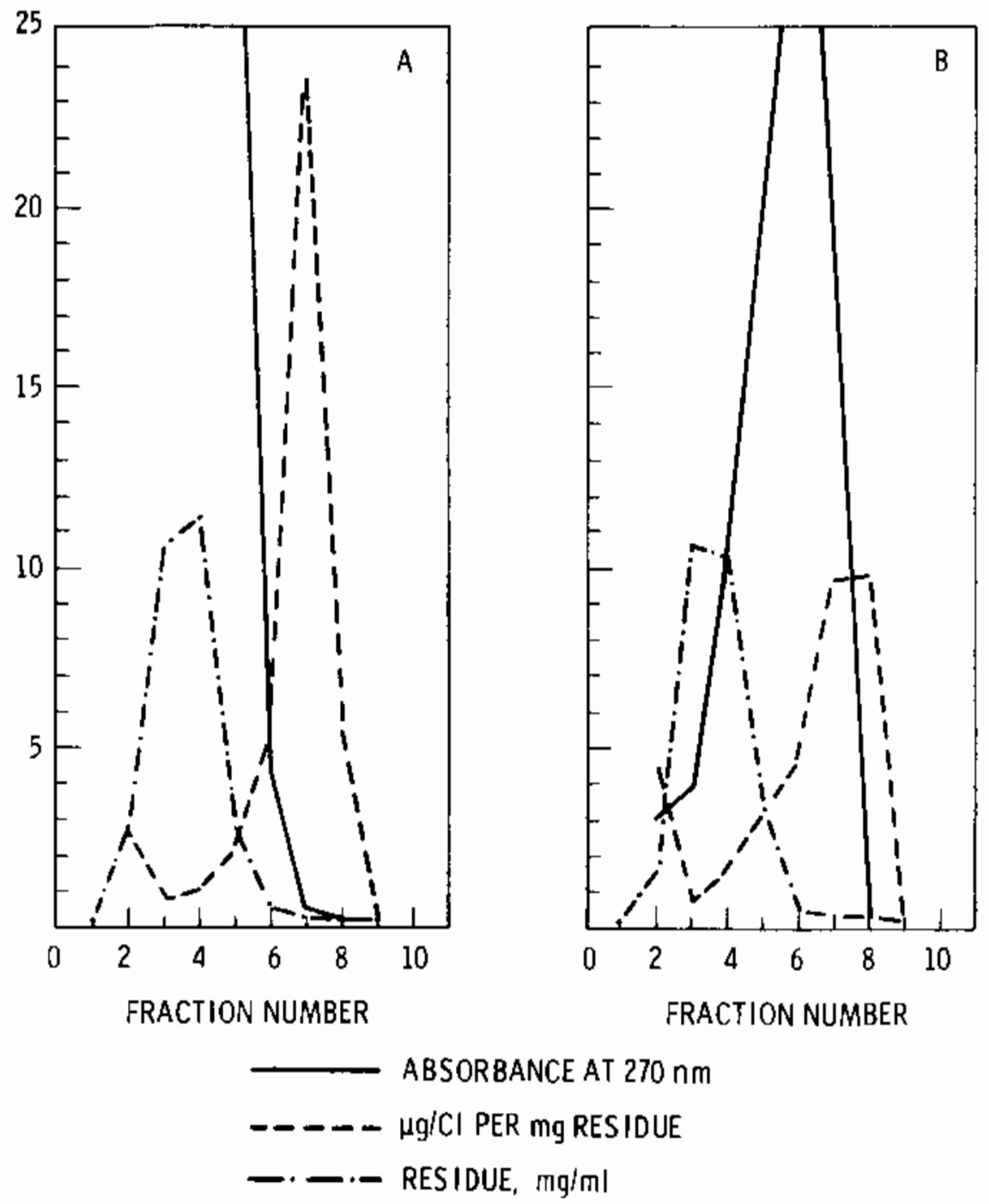

FIGURE 3. Characterization of Fractions from Gel Permeation Chromatography of Extracts of Tissues from (A) Control and (B) Exposed Rainbow Trout. 


\section{CONCLUSIONS AND RECOMMENDATIDNS}

- Given the time and exposure conditions of the 6-mo experiment, there was no apparent long-term effect of low-level chlorination on rainbow trout mortality or growth.

- Chloroform (35-40 $\mu \mathrm{g} / 1, \mathrm{ppb})$, is produced from the chlorination of $2 \mathrm{ppm}$ chlorine in Columbia River water.

- Rainbow trout tissues from the first chronic chlorination by-products exposure at 6-mo were analyzed for chlorinated organics. No significant differences in chlorinated organics were found between exposed and control fish.

- Measurement of chloroform in the freshwater exposure apparatus using headspace technique shows that chloroform levels range from $1 \mu \mathrm{g} / \mathrm{l}$ to 0.5 $\mu \mathrm{g} / 1$. Chloroform concentrations in the unchlorinated controls range from non-detectable to $0.5 \mu \mathrm{g} / 7$.

- Although 6-mo studies of chiorination by-products were conducted, examination of effects of chronic low level exposure on reproduction were not conducted. Studies of effects of chronic exposures to chlorination by-products on reproductive ability and behavior are recommended. 


\section{LITERATURE CITED}

American Public Health Association, American Water Works Association, and Water Poliution Control Federation. 1975. Standard Methods for the Examination of Water and Wastewater, 14th ed. APHA, Washington, D.C. 1193 p.

Anderson, D. R., and E.W. Lusty. 1980. Acute toxicity and bioaccumulation of chloroform to four species of freshwater fish: Salmo gairdneri; Rainbow trout; Lepomis macrochirus, Bluegill; Micropterus salmoides, Largemouth bass; and Ictalurus punctatus, Channel catfish. NUREG/CR-0893. Nuclear Regulatory Comission, Washington, D.C. 36 pp. *

Bean, R. M., D. C. Mann and R. G. Riley. 1980. Analys is of organohalogen products from chlorination of natural waters under simulated biofouling control conditions. NUREG/CR-1301. Nuclear Regulatory Comisnission, Washington, D.C. 90 p.*

Brungs, W. A. 1973. Effects of residual chlorine on aquatic life. J. Water Pol1. Contr. Fed. 45(10):2180-2193.

Brungs, W. A. 1976. Effects of waste water and cooling water chlorination on aquatic life. pp. 1-44. In: Disinfection Seminar Statements. Seattle, WA. May 26, 1976. Washington State Dept. of Ecology, 0lympia, WA.

Bush, B., R. S. Narang and S. Syrotynski. 1977. Screening for haloorganics in New York state drinking water. Bull. Env. Cont. and Toxicol. 18:436-440.

Dunnett, C. W., 1964. New tables for multiple comparison with a control. Biometrics, $3: 1-21$.

Gore, K. L., J. M. Thomas, L. D. Kannberg and D. G. Watson. 1977. Evaluation of Haddam Neck (Connecticut Yankee) nuclear power plant. Environmental Impact Prediction Based on Monitoring Programs, 8NWL-2151, Nuclear Regulatory Commission. 182 pp. pius Appendixes.

Kueh1, D. W., and E.W. Leonard. 1978. Isolation of xenobiotic chemicals from tissue samples by gel permeation chromatography. Anal. Chem. 50:182-185.

Sprague, J. B. 1973. "The ABCs of pollutant bioassay using fish," pp. 6-30. In: Biological Methods for the Assessment of Water Quality. ASTM-STP-528, American Society for Testing and Materiats.

\#Available for purchase from the NRC/GPO Sales Program, U.S. Nuclear Regulatory Commission, Washington, DC 20555, and the National Technical Information Service, Springfield, VA 22161. 



\section{DISTRIBUTION}

No. of

Copies

OFFSITE

A. A. Churm

DOE Patent Division

9800 S. Cass Avenue

Argonne, IL 60439

Dr. Phillip R. Reed

Bob Samworth

John C. Lehr

U.S. Nuclear Regulatory

Commission

7915 Eastern Avenue

Silver Springs, MD 20901

265 NRC Division of Technical Information and Document Control

Washington, DC 20555

2 DOE Technical Information Center

D. R. Anderson

2521 N. 40th, No. 1

Seattle, WA 98103

Dr. Robert Broxton

Electric Power Research Institute

PO Box 10412

Palo Alto, CA 94303

Dr. Dennis T. Burton

Academy of Natural Sciences of Philadelphia

Benedict Estuarine Research Laboratory

Benedict, MD 20612
No. of

Copies

Dr. Will Davis

U.S.E.P.A.

Gulf Breeze Environmental Research Laboratory

Wadmalaw Island, SC 19487

Dr. R. E. Hillman

W. F. Clapp Laboratories

Washington Street, P.O. Box $\mathrm{AH}$

Duxbury, MA 02332

Dr. Donald Johnson

Dept. Environmental Sciences and Engineering

School of Public Health

University of North Carolina

Chapel Hill, NC 27514

Dr. George R. Helz

Chemistry Dept.

University of Maryland

College Park, MD 20742

Dr. Milton H. Lietzke

PO Box $X$

Oak Ridge National Laboratory

Oak Ridge, TN 37830

Dr. J. S. Mattice

PO Box $X$

Oak Ridge National Laboratory

Oak Ridge, TN 37830

Dr. John Lum

U.S.E.P.A.

401 M Street S.W.

WH552

Washington, DC 20460 
No. of

Copies

Dr. Roy Nakatanj

Dr. Quent in J. Stober

FRI WH-10

University of Washington

Seattle, WA 98195

$\mathrm{Dr}$. Thamas 0 . Thatcher

Rt 2 Box 113

Sequim, WA 98382

F. C. Tone

Florida Marine Research Facility

Sailfish Drive

Ponce Inlet

Daytona Beach, FL 32019

Ronald L. Raschke

U.S. EPA

S.E. Water Laboratory

Batley Road

Athens, GA 30601
No. of

Copies

ONSITE

50 Pacific Northwest Laboratory

RM Bean (32)

CI Gibson

KE Harding (4)

OC Mann

TL Page

RG Riley

RE Schirmer

NM Sherer

RE wildung

Publishing Coordination (2)

Technical Information (5) 


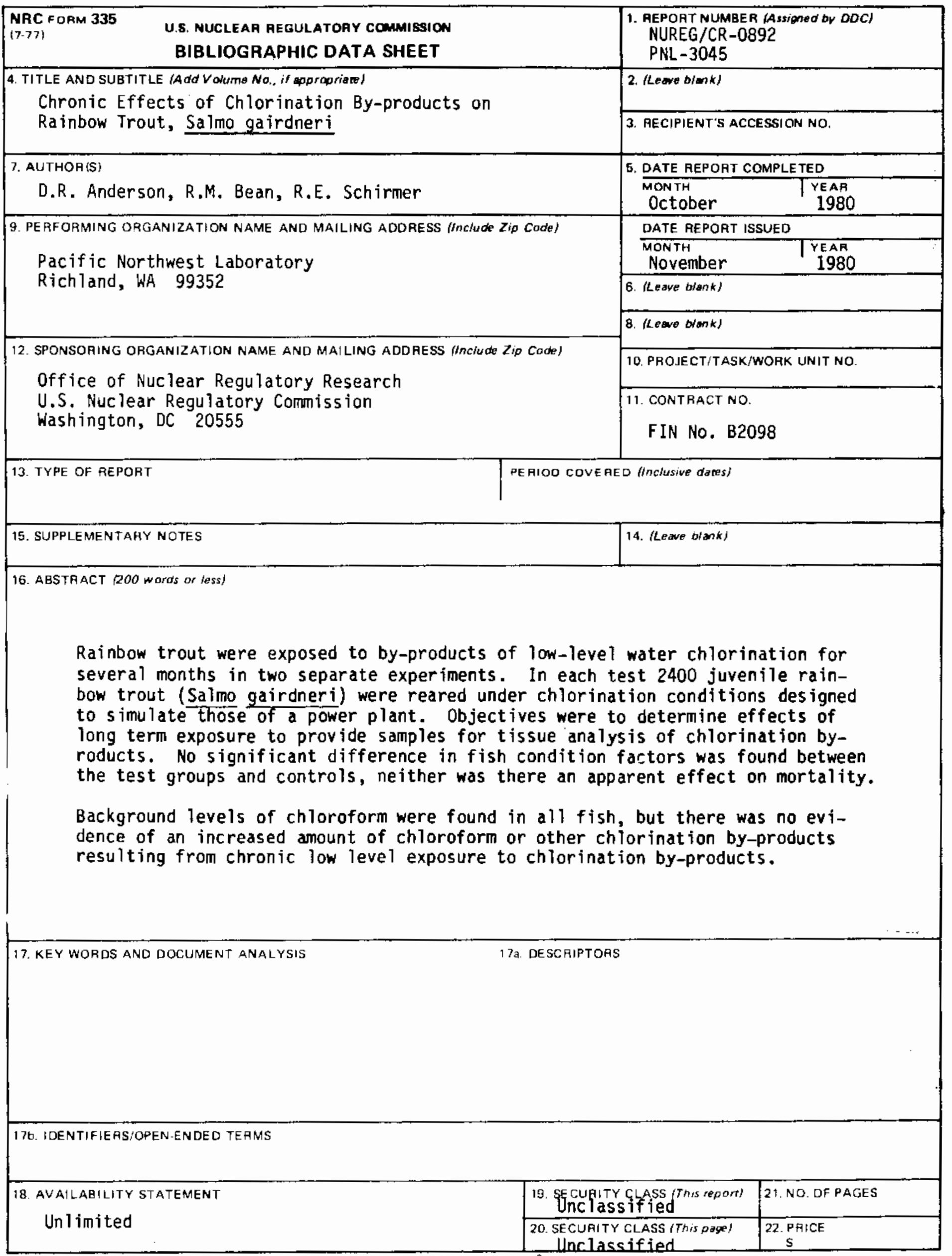


